\title{
Pengembangan e-Government di Pemerintahan Daerah Dalam Rangka Mewujudkan Smart City (Studi di Pemerintah Daerah Kota Malang)
}

\author{
Nurjati Widodo ${ }^{\text {a }}$ * \\ ${ }^{a}$ Universitas Brawijaya, Malang, Jawa Timur, Indonesia
}

\section{INFORMASI ARTIKEL}

\section{Article history:}

Dikirim tanggal: 05 Oktober 2016

Revisi pertama tanggal: 24 Oktober 2016

Diterima tanggal: 15 November 2016

Tersedia online tanggal: 28 November 2016

Keywords: e-government, smart city, Kota Malang

\begin{abstract}
This study aims to analyze the development of electronic government which is increasingly prevalent in local governance in order to realize smart city. Smart city is a manifestation of a city that provide excellent public services for the community, and create openness to the public by relying on the power of ICT. The concept of smart city has six indicators, namely smart governance, smart economy, smart live, smart living, smart people, and smart mobility. The object of this research is the development of electronic government in the Local Government of Malang City.
\end{abstract}

\section{INTISARI}

Penelitian ini bertujuan untuk menganalisis pengembangan electronic government yang semakin marak di pemerintahan daerah dalam rangka mewujudkan smart city. Smart city merupakan perwujudan suatu kota menjadi kota pintar dengan tujuan menciptakan suatu pelayanan yang prima bagi masyarakat, dan menciptakan keterbukaan kepada masyarakat dengan mengandalkan kecanggihan TIK. Konsep smart city memiliki enam indikator, yaitu smart governance, smart economy, smart live, smart living, smart people, dan smart mobility. Objek penelitian ini adalah pengembangan electronic government di Pemerintah Daerah Kota Malang.

2016 FIA UB. All rights reserved.

\section{Pendahuluan}

Akhir-akhir ini, kebutuhan akan tersedianya informasi yang mudah di akses, cepat, tepat dan akurat menjadi salah satu dasar pengembangan pemanfaatan teknologi informasi di lingkungan pemerintahan. Kebutuhan informasi ini bahkan sudah menjadi salah satu kebutuhan utama, karena pada umumnya pemerintah memiliki tugas dan tanggung jawab terhadap pelayanan masyarakat.

Perkembangan teknologi informasi dan komunikasi ini juga sangat menguntungkan dibandingkan dengan cara-cara manual atau tradisional. Hal itu dibuktikan dengan semakin cepatnya masyarakat dalam mendapatkan informasi melalui berbagai teknologi informasi dan komunikasi yang semakin baik. Beberapa negara maju saat ini sudah mulai memanfaatkan teknologi informasi dan komunikasi terbaru yang bersifat digital dan melahirkan sebuah bentuk mekanisme birokrasi pemerintahan baru, yang disebut sebagai Electronic Government (E-government).

E-government adalah penyelenggaraan pemerintahan dengan menggunakan teknologi informasi dan telekomunikasi untuk meningkatkan kinerja pemerintah, serta memenuhi kebutuhan masyarakat akan transparansi dan akuntabilitas informasi keuangan pemerintah dengan tujuan mencapai good governance. Menurut Indrajit dalam Akadun (2009:131), 
e-government adalah penggunaan internet untuk melaksanakan urusan pemerintah dan penyediaan pelayanan publik agar menjadi lebih baik dan berorientasi pada pelayanan masyarakat.

Pemerintah Indonesia dewasa ini sudah mulai menggunakan e-government dalam mempublikasikan informasinya. Salah satu contohnya adalah pemerintah dapat berinteraksi dengan masyarakat dengan penggunaan e-mail. Sebagian besar e-mail digunakan sebagai layanan pengaduan. Contoh selanjutnya dapat dilihat dari penggunaan Sistem Informasi Pengelolaan Keuangan Daerah (SIPKD).

Sistem Informasi Pengelolaan Keuangan Daerah (SIPKD) adalah aplikasi terpadu yang digunakan sebagai alat bantu pemerintah daerah yang digunakan meningkatkan efektivitas implementasi dari berbagai regulasi bidang pengelolaan keuangan daerah yang berdasarkan pada asas efesiensi, ekonomis, efektif, transparan, akuntabel dan auditabel. Penjelasan di atas dapat disimpulkan bahwa terbentuknya e-government ini salah satunya berorientasi pada pelayanan publik, di mana dengan adanya pelayanan publik yang efektif dan efisien dapat menunjang pada terciptanya good governance.

Pelayanan publik menjadi langkah awal dalam perwujudan good governance di Indonesia. Namun pada kenyataanya, penyelenggaraan pelayanan publik yang dilakukan oleh pemerintah pusat maupun pemerintah daerah masih dihadapkan pada pelayanan yang belum efektif dan efisien serta kualitas sumber daya manusia yang belum memadai. Hal ini terlihat dari masih banyaknya pengaduan dari masyarakat baik secara langsung maupun tidak langsung, seperti melalui media massa yang menuntut peningkatan kualitas pelayanan publik. Permasalahan utama saat ini adalah kurang tanggapnya pemerintah dalam merespon keinginan masyarakat.

Seperti yang terjadi di Kota Malang, pada tahun 2012 pelayanan publik masih kurang memuaskan, hal ini dapat dibuktikan dengan banyaknya keluhan dari masyarakat tentang Satuan Kerja Perangkat Daerah (SKPD) yang masih bekerja dengan waktu yang relatif lambat. Masyarakat menganggap pelayanan publik di Kota Malang ini masih jauh dari efektif dan efisien. Banyak masyarakat yang dilibatkan sebagai objek penarikan uang sumbangan. Sementara untuk pengawasan kebijakannya, partisipasi masyarakat masih rendah. Sehingga Tahun 2012, Malang Coruption Watch (MCW) membuat satu posko pengaduan keliling yang ditujukan kepada masyarakat Kota Malang tentang pelayanan publik di Malang Raya. Hasil survei yang dilakukan MCW membuktikan bahwa masih banyaknya masyarakat yang menganggap kualias pelayanan publik di Kota Malang ini masih jauh dari kata memuaskan (Sukarelawati, 2013).
Melihat permasalahan di atas, peningkatan kualitas pelayanan publik di Kota Malang merupakan salah satu isu yang sangat penting. Hal ini terjadi karena disatu sisi tuntutan masyarakat terhadap kualitas pelayanan semakin besar sementara praktek penyelenggara pelayanan tidak mengalami perubahan yang berarti. Masyarakat setiap waktu menuntut pelayanan publik yang berkualitas, meskipun tuntutan tersebut sering tidak sesuai dengan harapan karena pelayanan publik yang terjadi selama ini masih berbelit-belit, lambat, mahal, dan melelahkan. Untuk memperbaiki pelayanan publik yang belum optimal itu maka harus dilakukan reformasi birokrasi. Konsep dasar dari reformasi birokasi adalah melakukan perubahan dan perbaikan yang lebih baik lagi. Untuk itu, demi tercapainya pelayanan yang lebih baik lagi, reformasi birokrasi yang dilakukan Pemerintah Kota Malang adalah penggunaan teknologi informasi dan komunikasi dalam pelayanan publik. Melalui penggunaan e-government dalam pemerintah Kota Malang, diharapkan Pemerintah Kota malang dapat memperbaiki pelayanan publik menjadi lebih baik.

Perkembangan pelayanan publik yang manual atau sederhana menjadi e-government ini dapat dikembangkan oleh pemerintah menjadi konsep smart city. Smart city sendiri dapat diartikan sebagai perwujudan suatu kota menjadi kota pintar dengan tujuan menciptakan suatu pelayanan yang prima bagi masyarakat, dan menciptakan keterbukaan kepada masyrakat dengan mengandalkan kecanggihan teknologi informasi dan komunikasi. Konsep smart city itu sendiri memiliki enam indikator, yaitu smart governance, smart economy, smart live, smart living, smart people, dan smart mobility.

Saat ini, di Indonesia sudah ada tiga kota yang dapat disebut sebagai smart city, yaitu Jakarta, Bandung, dan Surabaya. Kota Jakarta, konsep smart city yang dilakukan yaitu dengan menerapkan e-government didalam pemerintahannya, dimana pemerintah Jakarta melibatkan masyarakat dalam pengambilan keputusan. Kota Bandung, penerapan smart city yang dilakukan yaitu dalam bidang transportasi. Kota Surabaya, kota ini sudah mendapatkan penghargaan Smart City Awards pada Tahun 2011. Penghargaan itu diberikan kepada Kota Surabaya karena kota tersebut dianggap sudah berhasil menjalankan prinsip-prinsip smart city, yakni smart government, smart environment, dan smart living.

Kota Malang sendiri, dalam mewujudkan smart city dikota ini harus dapat menjalankan enam indikator dari smart city itu sendiri. Kota Malang dapat mencontoh tiga kota di atas yang sekiranya telah mendapatkan label smart city, seperti penerapan e-government didalam pemerintahannya, penggunaan sensor pada lampu merah dan tempat-tempat kotor. Salah satu upaya yang dilakukan Pemerintah Kota Malang dan merupakan satu terobosan baik adalah pembuatan program Anugerah Inovasi dan Kreativitas Informasi Digital (AIKID) yang 
dibuat oleh Dinas Komunikasi dan Informasi (Diskominfo) Kota Malang dalam rangka memonitoring, mengevaluasi, dan meningkatkan pemanfaatan teknologi informasi dan komunikasi oleh SKPD di Pemerintah Kota Malang.

Program AIKID ini merupakan sebuah program penghargaan yang dibuat oleh Dinas Komunikasi dan Informasi (Diskominfo) Kota Malang kepada seluruh SKPD yang mampu inovatif dan kreatif dalam memberikan pelayanan publik kepada masyarakat dengan menggunakan teknologi informasi dan komunikasi modern. Tujuan dari program AIKID ini adalah untuk bisa memotivasi SKPD agar dapat meningkatkan pengembangan dan pemanfaatan TIK dalam rangka penyebarluasan informasi publik dan meningkatkan kualitas pelayanan publik di lingkungan Pemerintah Kota Malang. Program AIKID ini melibatkan dua kategori SKPD, yaitu SKPD kelurahan, yang berjumlah 57 kelurahan di Kota Malang dan SKPD non kelurahan yang berjumlah 42 SKPD, yang meliputi Inspektorat, Sekretariat Daerah, Sekretariat DPRD, dinas, badan, kantor, satuan, dan kecamatan. SKPD-SKPD yang diperlombakan ini akan dinilai oleh dewan juri, dan akan diberikan penghargaan dengan kategori peserta.

Program AIKID ini dapat dikatakan sebagai fasilitas pelayanan (facilitating service) dan bertujuan untuk meningkatkan pelayanan tambahan (supporting service) di Pemerintahan Kota Malang. Menurut Sutopo (2003: 15), Fasilitas pelayanan atau facilitating service merupakan suatu pelayanan tambahan kepada pelanggan. Sedangkan, pelayanan tambahan atau supporting service merupakan pelayanan tambahan atau pendukung untuk meningkatkan nilai pelayanan atau untuk membedakan dengan pelayanan-pelayanan dari pihak pesaingnya. Program AIKID dikatakan facilitating service karena merupakan sebuah program tambahan yang dibuat oleh Pemerintah Kota Malang, dan dikatakan untuk meningkatkan supporting service karena pada dasarnya tujuan dari AIKID ini adalah program tambahan untuk meningkatkan dan mendukung inovasi dan kreativitas seluruh SKPD Kota Malang memiliki tujuan untuk meningkatkan pelayanan publik melalui penggunaan teknologi informasi dan komunikasi yang modern dan juga demi mewujudkan label smart city.

\section{Teori}

\subsection{Good Governance}

Inovasi baru administrasi publik adalah merupakan konsep "governance". Rewansyah (2010:80) mengatakan "governance diartikan dengan kepemimpinan yang bahasa inggrisnya the act, fact manner of governing. Dengan demikian governance atau pemerintah merujuk pada kegiatan atau proses, suatu cara atau metode, tindakan dan sistem penyelengaraan pemerintahan.

\subsection{Pelayanan Publik}

Konsep pelayanan terjadi diberbagai bidang dan sangat dibutuhkan oleh setiap manusia. Menurut Sinambela (2010:3), pada dasarnya setiap manusia membutuhkan pelayanan diberbagai bidang, bahkan dapat dikatakan secara jelas bahwa pelayanan sangat tidak dapat dipisahkan dengan manusia. Pelayanan publik pada hakikatnya adalah sebuah rangkaian kegiatan yang dilaksanakan secara rutin, dimana proses pelayanan dilakukan dengan saling memenuhi kebutuhan antara pemberi pelayanan terhadap penerima pelayanan. Pelayanan publik menurut Undang-Undang Nomor 25 pasal 1 ayat 1 Tahun 2009 adalah kegiatan atau rangkaian kegiatan dalam rangka pemenuhan kebutuhan pelayanan sesuai dengan peraturan perundang-undangan bagi setiap warga negara dan penduduk atas barang, jasa, dan/ atau pelayanan administratif yang disediakan oleh penyelenggara pelayanan publik.

Gronroos dalam Sutopo (2003: 15) mengelompokan pelayanan publik menjadi tiga kelompok, diantaranya yaitu:

a) Core Service, adalah pelayanan yang ditawarkan kepada pelanggan, yang merupakan produk utama;

b) Facilitating Service, adalah fasilitas pelayanan tambahan kepada pelanggan. Misalnya pelayanan costumer service pada kantor pos; dan

c) Supporting Service, merupakan pelayanan tambahan atau pendukung untuk meningkatkan nilai pelayanan atau untuk membedakan dengan pelayanan-pelayanan dari pihak pesaingnya. Misalnya pembelian tiket pesawat pada kantor pos.

\subsection{Sistem Informasi Manajemen}

Dalam administrasi publik, sistem informasi manajemen merupakan suatu ilmu yang sangat penting, karena untuk dapat mencapai tujuan dari suatu organisasi publik melibatkan berbagai sumber daya. Salah satu sumber daya yang dilibatkan adalah informasi. Dalam sistem informasi manajemen publik, terdapat beberapa komponen di dalamnya, yaitu sebagai berikut:

a) Sistem informal merupakan sistem diskursus dan interaksi antara individu dan kelompok kerja organisasi. Karakteristik yang menonjol adalah perlunya memperhitungkan sifat politik dan budaya organisasi yang termanifestasi dalam negosiasi dan tawar-menawar;

b) Sistem formal meliputi sistem aturan, batasan organisasi, dan batasan wewenang. Hal ini biasanya diorganisasikan secara hierarkis yang meliputi aturan organisasi dan metode kerja yang dikaitkan dengan berbagai macam profesi yang ada di dalam organisasi;

c) Sistem komputer formal meliputi aktivitas organisasi melalui formalisasi dan pemrograman. Sistem komputer merupakan sistem yang berinteraksi dengan faktor manusia dan dengan aturan kerja. Prinsip yang 
diterapkan adalah bebas nilai, tetapi pada prakteknya sistem informasi manajemen dan organisasi diwarnai dengan nilai-nilai yang mendesain sistem. Efektivitasnya, tergantung pada kecepatan, realibilitas, ketepatan, produksi, dan efisiensi;

d) Sistem komputer informal dikaitkan dengan penanganan komputer secara informal dan penggunaan sistem formal serta jaringan komputer sebagai sarana penyatuan informasi yang tidak terstruktur dan informasi informal. Sistem informasi informal merupakan komponen dalam sistem informasi manajemen yang relatif baru dibandingkan dengan komponen yang lainnya, tetapi memberikan kemungkinan perbaikan penyesuaian antara sistem informal dengan organisasi dan sistem formal; dan

e) Sistem eksternal, informal, dan formal tidak ada organisasi hidup dalam isolasi dan keterkaitan antara organisasi dengan lingkungan eksternal harus terjadi (Sutabri, 2003: 115).

Kelima komponen itu saling berkaitan satu dengan yang lain, komponen sistem informasi manajemen publik itu dikembangkan dengan melihat perkembangan yang terjadi.

\subsection{Electronic Government}

Konsep e-government atau electronic government, yang merupakan suatu sistem pemerintahan yang dalam pelaksanaan kepemerintahannya menggunakan teknologi informasi terbaru. E-government ini dapat dikatakan sebagai inovasi yang tepat didalam pemerintahan, itu dikarenakan dengan adanya e-government ini dapat membantu pemerintahan menjadi lebih efektif dan efisien, dan juga membuat masyarakat memahami apa yang dilakukan oleh suatu pemerintahan.

E-government berkembang mengadopsi electronic business, electronic commerce, dan electronic market yang lebih dulu mengaplikasikan teknologi tersebut dalam institusi bisnis dengan menggunakan jasa internet (Akadun, 2009:130). Menurut Wyld dalam Akadun (2009:131) menyebutkan "e-government adalah pemrosesan secara elektronik yang digunakan pemerintah untuk mengkomunikasikan, menyebarkan atau mengumpulkan informasi sebagai fasilitas dan perizinan untuk suatu tujuan". Menurut Indrajit yang dikutip dalam Akadun (2009:131), e-government adalah penggunaan teknologi informasi oleh pemerintah yang memungkinkan pemerintah untuk mentransformasikan hubungan dengan masyarakat, dunia bisnis dan pihak yang berkepentingan, dan dalam prakteknya, $e$ government adalah penggunaan internet untuk melaksanakan urusan pemerintah dan penyediaan pelayanan publik agar lebih baik dan berorientasi pada pelayanan masyarakat.

Dari jabaran di atas dapat disimpulkan bahwa $e$ government adalah penggunaan teknologi informasi dan komunikasi terbaru dalam pemerintahan yang berfungsi untuk mengkomunikasikan, menyebarkan atau mengumpulkan informasi yang berguna bagi masyarakat. Terciptanya e-government diharapkan akan menciptakan interaksi yang ramah, nyaman, transparan dan murah antara pemerintah dan masyarakat $(\mathrm{G} 2 \mathrm{C})$, pemerintah dan bisnis (G2B) dan hubungan antar pemerintah (G2G/ inter agency relationship).

\section{Metode Penelitian}

Penelitian ini adalah penelitian deskriptif yang dilakukan dengan pendekatan kualitatif. Penelitian ini bertujuan untuk mendeskripsikan, mencatat, menganalisis dan menginterpretasikan mengenai kondisi saat ini, dengan kata lain penelitian jenis deskriptif kualitatif bertujuan untuk memperoleh informasiinformasi dari keadaan yang sudah terjadi.

Lingkup penelitian ini adalah pengembangan electronic government yang diselenggarakan di Pemerintah Daerah Kota Malang dalam rangka mewujudkan smart city. Analisis pengembangan ini dilakukan dengan melihat 6 indikator konsep smart city, yaitu:

a) smart governance;

b) smart economy;

c) smart live;

d) smart living;

e) smart people; dan

f) smart mobility.

Metode Pengumpulan data dengan dokumentasi, observasi, wawancara kepada aktor yang terlibat dalam penyusunan anggaran.

Analisis data merupakan proses pengorganisasikan dan mengurutkan data ke dalam pola, kategori dan satuan uraian dasar sehingga dapat ditemukan tema dan dirumuskan hipotesis kerja seperti yang disarankan oleh data (Moleong, 1999:103). Dalam penelitian ini metode yang digunakan adalah analisis data interaktif (interaktive model of analysis) dari Miles Huberman dan Saldana yang meliputi pengumpulan data, penyajian data, penarikan kesimpulan dan verifikasi, dan yang terakhir adalah kondensasi data.

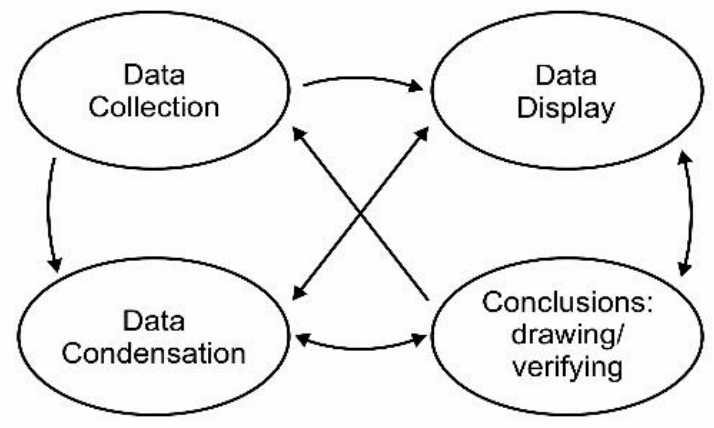

Gambar 1

Komponen dalam Analisa Data (Interactive Model) Sumber: Miles Huberman, dan Saldana (2014) 


\section{Hasil Penelitian dan Pembahasan}

\subsection{Jumlah Hasil Yang Dapat Dikeluarkan}

Efektivitas pada dasarnya menekankan pada pencapaian hasil dari suatu organisasi atau program. Hasil yang dikeluarkan dalam hal ini merujuk pada seberapa efektifnya pelaksanaan Program AIKID ini terhadap tujuan-tujuan yang dicanangkan, yaitu terciptanya inovasi dan pengingkatan kualitas situs. Jika kedua hal itu terpenuhi, maka akan terjadi peningkatan kualitas pelayanan publik, peningkatan kualitas $e$ government, dan perwujudan smart city. Suatu program pemerintah dikatakan berhasil apabila program itu dapat menjawab semua tujuan-tujuan yang dicanangkan sebelum program itu berlangsung.

Setelah dua tahun pelaksanaan program ini, peneliti melihat adanya perbedaan didalam situs-situs tersebut. Mulai dari situs kelurahan, dinas, badan - badan, dan lain sebagainya sudah terlihat perkembangannya walaupun ada beberapa yang tidak signifikan dalam perkembangannya. saat ini dalam setiap situs SKPD sudah terdapat banyak informasi-informasi penting sesuai bidangnya masing-masing.

Terdapat satu permasalahan pada hasil ini, dimana peneliti melihat adanya beberapa situs yang dinilai masih tidak ada perubahan. Beberapa situs yang peneliti akses tidak memiliki kualitas seperti situs-situs lainnya. Hal ini disebabkan karena penulis melihat tidak adanya inovasi pada situs tersebut, tidak memiliki informasi yang dibutuhkan, tidak memiliki informasi yang up to date, dan ada juga situs yang tidak bisa diakses.

Hasil selanjutnya dari Program AIKID ini adalah terciptanya inovasi, dimana inovasi ini terdiri dari inovasi kelembagaan dan inovasi teknologi. Pada inovasi kelembagaan dilatar belakang menggunakan teori Halversen dkk (dalam Suwarno, 2008:43) yang memiliki enam jenis inovasi, namun yang dapat masuk kedalam program ini hanya empat saja, yaitu sebagai berikut:

a) Layanan baru atau layanan perbaikan

Indikator pertama ini menjelaskan tentang inovasi merupakan sebuah pelayanan baru atau pelayanan yang diperbaiki. Hasil penelitian penulis menemukan bahwa program ini dapat dimasukan kedalam indikator ini, karena program ini yang diselenggarakan oleh Diskominfo Kota Malang merupakan suatu program yang dibuat untuk mengatasi permasalahan, dimana program ini berfungsi untuk perbaikan pelayanan dan perbaikan kualitas situs pada SKPD Kota Malang yang pada tahun 2013 lalu dinilai kurang memuaskan.

b) Inovasi proses

Inovasi proses merupakan perubahan dalam proses penyediaan pelayanan atau produk. Berdasarkan hasil penelitian yang dilakukan oleh penulis, terdapat inovasi proses pada program ini. hal yang dapat dilihat adalah sebelum ada program ini terdapat banyak permasalahan pelayanan yang terjadi di Kota Malang akan tetapi setelah adanya program ini yang menghasilkan inovasi pada setiap situs SKPD memberikan dampak yang lebih baik.

c) Inovasi administrasi

Inovasi administrasi merupakan penggunaan instrumen kebijakan baru sebagai hasil dari perubahan kebijakan. Jika dikaitkan dengan inovasi ini, dapat dilihat dari segi kebijakan yang dibuat oleh pemerintah pusat maupun pemerintah daerah yang digunakan sebagai dasar hukum pada program ini. Hasil yang didapat peneliti, yaitu lahirnya program ini karena terdapat PERWALI Kota Malang No 50 Tahun 2010 tentang pedoman pelayanan informasi publik. Peraturan ini akan menjadi sebuah pijakan untuk Program AIKID ini agar menjadi program berkelanjutan setiap tahunnya untuk terus meningkatkan kualitas situs SKPD dan demi terciptanya smart city.

d) Inovasi Konseptual

Inovasi konseptual ini merupakan perubahan dalam outlook, seperti misalnya manajemen air terpadu atau mobility leasing. Berdasarkan hasil penelitian yang dilakukan, penulis melihat adanya perubahan pola pikir masyarakat. Berdasarkan hasil wawancara dengan beberapa masyarakat, mereka menganggap bahwa saat ini dengan adanya kualitas situs yang memadai, pelayanan publik di Kota Malang sudah lebih baik dari tahun - tahun sebelumnya. Hal ini karena pelayanan yang diberikan lebih efisien.

Pada teori Halversen dkk tersebut terdapat dua tipologi inovasi yang tidak masuk dengan program ini, yaitu inovasi sistem dan perubahan radikal. Maksud dari inovasi sistem pada teori ini yaitu adanya sistem baru atau adanya perubahan yang mendasar, dan maksud dari perubahan radikal yaitu pergeseran pandangan umum atau mental dari pegawai instansi pemerintah.

Pada program ini peneliti tidak menemukan adanya sistem baru, perubahan yang mendasar dan perubahan radikal tersebut. Hal ini terlihat pada situs SKPD tersebut, dimana setiap SKPD sebenarnya sudah mempunyai situs sebelum adanya program ini. Program AIKID ini memang memberikan perubahan pada segi kualitas situs, namun tidak ada perubahan yang mendasar ataupun perubahan yang bersifat radikal. Perubahan yang terjadi adalah perkembangan situs setelah adanya program ini, dan untuk Program AIKID ini juga tidak ada perubahan sistem dari tahun pertama pelaksanaan ke tahun kedua. Perubahan yang terjadi pada program ini yaitu melakukan penambahan jumlah peserta, di mana pada tahun 2014 menambahkan SKPD kelurahan.

Pada program ini juga memperlihatkan adanya inovasi teknologi, dimana saat ini telah digunakannya $e$ government. Pada hal ini, Program AIKID dapat dianalisiskan dengan beberapa kerangka dari $e$ government itu sendiri. Pertama adalah government to citizens (G2C), dimana G2C ini merupakan penggunaan 
teknologi informasi oleh pemerintah untuk memperbaiki hubungan interaksi dengan masyarakat. Pada program ini terlihat adanya G2C, hal ini terlihat dari hasil-hasil yang di keluarkan dari program ini dapat memberikan kemudahan bagi masyarakat untuk berinteraksi dengan pemerintah. Hasil yang dimaksud ini adalah pelayanan melalui situs setiap SKPD yang sudah mengalami perkembangan setelah pelaksanaan program ini. satu permasalahan yang ada yaitu masih terdapat beberapa situs SKPD yang tidak memberikan pelayanan yang baik dalam situsnya. Seperti layanan pengaduan yang ada pada setiap situs. Masih banyak situs yang tidak memberikan tanggapan untuk pengaduan, dan juga kurang baiknya dalam pengelolaan informasi.

Program AIKID ini juga dapat dimasukan pada government to business (G2B), dimana peneliti melihat dari beberapa situs yang diakses terdapat pelayananpelayanan yang dapat digunakan untuk melakukan hubungan dengan sektor bisnis. Hal ini terlihat dari layanan perijinan pendirian bangunan yang saat ini dapat diakses, lalu terdapat juga pelayanan informasi terkait pajak-pajak yang ada di Kota Malang. Pada hal ini penulis juga melihat dari banyaknya situs-situs SKPD, terdapat beberapa situs yang dapat menarik investor untuk menanamkan investasinya di Kota Malang. Dengan kata lain, jika situs-situs terus dikembangkan, maka akan membuka peluang untuk menarik investor ke Kota Malang ini dan tentunya akan meningkatkan pendapatan Kota Malang ini.

Berdasarkan hasil temuan di atas dapat dijelaskan bahwa Program AIKID ini menghadirkan inovasi yang cukup baik, dimana program ini masuk kedalam empat tipologi inovasi di atas. Hal ini disebabkan karena inovasi yang dihasilkan memberikan perubahan pelayanan yang diberikan oleh pemerintah menjadi lebih efisien, dan walaupun terdapat dua tipologi yang tidak masuk dalam program ini tetap membuat inovasi yang dihasilkan cukup baik. Hal ini tidak terlepas dari peningkatan kualitas situs SKPD di Kota Malang. Untuk mengukur kualitas situs yang merupakan hasil dari Program AIKID ini, dapat dilihat melalui metode WebQual 4.0 milik Barnes dan Vidgen dalam Sanjaya (2012:6), yaitu sebagai berikut:

a) Dimensi Kemudahan Penggunaan (Usability)

Pada indikator usability ini, hal-hal yang menjadi tolak ukur indikator ini mencakup Jika dilihat dari indikator yang terdapat pada usability ini yang mencakup kemudahan untuk dioperasikan, interaksi dengan website jelas dan dapat di mengerti, kemudahan untuk navigasi, kemudahan menemukan alamat website, tampilan yang atraktif, tepat dalam penyusunan tata letak informasi, tampilan sesuai dengan jenis website pemerintahan, dan adanya penambahan pengetahuan dari informasi website. Berdasarkan hasil penelitian yang dilakukan dengan mengakses situs-situs SKPD Kota Malang, program ini menjawab hampir semua indikator. Hal ini terlihat dari adanya perubahan pada setiap situs, dimana setiap situs mengalami perkembangan dari berbagai segi. Perkembangan ini dapat dilihat dari adanya kemudahan penggunaan pada situs. Penulis melihat dari berbagai situs SKPD Kota Malang dan hasilnya cukup baik, dimana hampir semua SKPD pada situsnya memiliki kemudahan penggunaan. Berdasarkan indikator pada usability. Hasil pengamatan penulis dengan banyaknya masyarakat yang diwawancarai, masyarakat juga sudah cukup puas dengan perubahan yang terjadi seperti yang tertera diatas.

b) Dimensi Kualitas Informasi

Tolak ukur pada indikator ini mencakup menyediakan informasi yang cukup jelas, menyediakan informasi yang dapat dipercaya, menyediakan informasi yang up to date, menyediakan informasi yang relevan, menyediakan informasi yang mudah dibaca dan dipahami, menyediakan informasi yang cukup detail, menyajikan informasi dalam format yang sesuai. Padahal ini terlihat bahwa Program AIKID dapat menjawab beberapa tolak ukur indikator ini. Pada kualitas informasi yang dihasilkan dari adanya Program AIKID ini cukup baik, dimana setiap SKPD menyediakan banyak informasi yang bersangkutan dengan SKPD tersebut. Informasi yang disajikan setiap SKPD dinilai dapat membantu dan juga memudahkan masyarakat. Hal ini dapat dilihat pada situs yang menyediakan layananlayanan, dimana layanan itu memiliki informasi yang sangat jelas. Beberapa contoh pada hal ini adalah layanan perijinan pada BP2T, layanan pembuatan surat-surat yang berhubungan dengan catatan sipil, dan juga layanan perijinan bidang kesehatan pada Dinas Kesehatan Kota Malang. Layanan yang disediakan sangat jelas, dimana berisi tentang prosedur-prosedur yang dibutuhkan oleh masyarakat. Pada hal ini, terdapat beberapa SKPD yang tidak memiliki kualitas informasi yang baik. Hal ini dibuktikan dengan kurang beragamnya informasi yang disediakan, dan juga kurang up to date. Contoh yang dapat diambil yaitu terdapat kekosongan pada standar informasi yang ada pada situs pemerintahan, yaitu seperti tidak adanya struktur organisasi, visi dan misi dari SKPD tersebut, dan juga berita terkait SKPD tersebut.

c) Kualitas Interaksi Pelayanan

Pada indikator ini, tolak ukur yang digunakan mencakup mempunyai reputasi yang baik, mendapatkan keamanan untuk melengkapi transaksi, rasa aman dalam menyampaikan data pribadi, kemudahan untuk menarik minat dan perhatian, adanya suasana komunitas, kemudahan untuk memberi masukan (feed back), dan tingkat kepercayaan yang tinggi atas informasi yang disampaikan website.

Jika dihubungkan dengan tolak ukur di atas, Program AIKID ini dapat menjawab beberapa tolak ukur tersebut. Hal ini terlihat dari kualitas interaksi, dimana 
saat ini kualitas interaksi SKPD menjadi lebih baik. Interaksi yang dimaksud dalam hal ini adalah seperti pelayanan - pelayanan yang saat ini telah disediakan oleh setiap SKPD di dalam situsnya. Terdapat satu permasalahan pada interaksi layanan ini, dimana pada beberapa situs terdapat fitur layanan komunitas yang disediakan untuk berkomunikasi dengan masyarakat, namun yang ditemukan oleh peneliti adalah ketidak aktifan layanan tersebut. Banyak masyarakat yang bertanya-tanya seputar pelayanan yang sediakan SKPD pada layanan komunitas itu, namun respon dari situs tersebut kurang aktif. Pada layanan pengaduan yang disediakan oleh banyak situs SKPD juga dianggap tidak aktif. Hal ini dibuktikan dengan hasil wawancara dengan 34 masyarakat yang 26 diantaranya menyatakan bahwa layanan pengaduan kurang aktif.

Berdasarkan pemaparan di atas dapat disimpulkan bahwa inovasi dan juga kualitas situs hasil yang dikeluarkan pada Program AIKID ini cukup baik, dimana penulis melihat adanya perubahan-perubahan seperti perkembangan inovasi pada banyak situs SKPD yang juga berpengaruh pada kualitas situs. Namun, peneliti juga menemukan ada beberapa situs SKPD yang menurut peneliti kurang memiliki inovasi dan kualitas situs yang belum cukup baik. Untuk tahun berikutnya, Diskominfo selaku penyelenggara harus lebih melihat kembali hasil yang didapat, karena seharusnya program ini bukan hanya program penghargaan saja, namun program ini juga harus meratakan kualitas situs yang ada.

\subsection{Tingkat Kepuasan}

Program yang dibuat oleh pemerintah nantinya akan memberikan dampak pada penerima program tersebut atau sasaran program tersebut. Pada program ini, dampak yang dirasakan yaitu berasal dari peserta dan juga masyarakat sebagai sasaran atau orientasi program tersebut. Berdasarkan pengamatan yang dilakukan oleh peneliti, maka dapat disimpulkan bahwa program ini sudah berjalan secara baik. Hasil yang dikeluarkan pada program ini memberikan perbedaan yang lebih baik dari sebelum program ini dilaksanakan. Hasil dari kuesioner yang dibagikan Diskominfo Kota Malang kepada seluruh SKPD juga hampir semua menyebutkan bahwa mereka puas dengan adanya program ini, karena dapat membantu mereka dalam penanganan situs-situs mereka yang dahulu memiliki sumber daya aparatur yang kurang mengerti namun sekarang telah lebih mengerti.

Terdapat suatu kendala dalam hal ini, yaitu program ini kurang melibatkan masyarakat. Banyak masyarakat yang tidak mengetahui tentang program ini. dari total pemilih pada polling AIKID yang berjumlah 64.542 pemilih dan total penduduk Kota Malang yang penulis dapatkan dari Dinas Kependudukan dan Catatan Sipil (Dispendukcapil) Kota Malang yang berjumlah 836.373 jiwa yang terdiri dari anak-anak, dewasa, dan lanjut usia.
Jika dilihat dari total pemilih pada polling AIKID, partisipasi masyarakat cukup baik. Jika dijadikan persen, menjadi $0,7 \%$ pemilih pada pada polling AIKID, namun jumlah pemilihnya tetap dianggap besar. Hal itu dikarenakan tidak mudah untuk meminta partisipasi masyarakat sebesar 64.542 jiwa.

Peneliti pada hal ini juga melihat kepuasan dari masyarakat dengan melakukan wawancara terkait inovasi dan kualitas situs yang dihasilkan. Pada wawancara yang dilakukan peneliti kepada 34 masyarakat pengguna situssitus SKPD Kota Malang, peneliti menilai bahwa inovasi dan kualitas situs harus lebih ditingkatkan. Hal itu disebabkan karena hasil yang penulis dapat dan juga tertera pada penyajian data masih banyak masyarakat yang belum puas dengan inovasi dan kualitas situs yang dihasilkan dari Program AIKID selama dua tahun. Masyarakat belum puas itu karena mereka melihat dari beberapa sisi yang juga sama dengan isi dari metode WebQual 4.0 milik Barnes dan Vidgen dalam Sanjaya (2012:6), dimana mereka cukup puas dengan usability yang ada, namun kurang puas dengan informasi yang tersedia di beberapa situs SKPD, dan juga kurang puas dengan interaksi yang ada pada beberapa situs SKPD.

Berdasarkan hal tersebut, perlu adanya pengembangan inovasi dan kualitas situs lagi agar masyarakat dapat lebih merasakan adanya perubahan yang lebih baik. Pada hal ini juga perlu adanya ketegasan dari Program AIKID ini, dimana masyarakat diikut sertakan dalam program ini atau hanya sebatas antar SKPD saja. Jika program ini melibatkan masyarakat, perlu sosialisasi yang lebih mendalam.

\subsection{Produk Kreatif}

Produk Kreatif dalam hal ini diartikan sebagai penciptaan hubungannya kondisi yang kondusif dengan dunia kerja, yang nantinya dapat menumbuhkan kreativitas dan kemampuan. Jika dianalisiskan dengan pengertian diatas, Program AIKID dapat dikatakan sebagai produk kreatif. Hal ini karena Pemerintah Kota Malang bersama dengan Diskominfo membuat program ini karena adanya permasalahan yang terdapat pada pelayanan publik seperti pelayanan yang lamban, berbelit, dan memakan waktu yang lama. Untuk itu adanya program ini diharapkan dapat memberikan perkembangan dan juga dapat meningkatkan pelayanan publik. Kreativitas Program AIKID ini dapat dijelaskan menurut pendapat Howkins dalam Suyana (2013:25).

a) Peninjauan/ Pengkajian Ulang (Review)

Sebelum Program AIKID dibuat oleh Pemerintah Kota Malang melalui Diskominfo Kota Malang. pemerintah kota melihat permasalahan-permasalahan yang ada. Permasalahan yang ada yaitu masih kurang puasnya masyarakat dengan pelayanan publik yang diberikan pemerintah kota. Berdasarkan pengamatan yang dilakukan peneliti, dapat terlihat bahwa sebelum 
penyelenggaraan Program AIKID ini, Diskominfo melakukan peninjauan ulang. Maksud dari peninjauan ulang dalam hal ini adalah seberapa besar permasalahan yang ada pada pelayanan publik itu. Peninjauan ulang juga dilaksanakan pada rangkaian yang akan dilaksanakan dalam program ini, dimana hal ini berguna untuk mementukan apa yang menjadi tujuan dari Program AIKID ini.

b) Inkubasi (Incubation)

Inkubasi dalam hal ini memiliki pengertian sebagai pembiaran ide-ide untuk saling mencocokan sendiri. Pada program AIKID ini, peneliti melihat inkubasi didalam program ini, dimana inkubasi yang dimaksud terdapat pada perlombaan situs yang ada dalam rangkaian program ini. Inkubasi yang dilakukan untuk memberikan waktu dan ruang kepada seluruh SKPD untuk berinovasi dan berkreativitas didalam situs mereka masing-masing.

c) Mengkhayal (Dreams)

Mengkhayal pada hal ini diartikan sebagai mimpimimpi yang nantinya akan tercapai setelah adanya Program AIKID ini. peneliti melihat adanya mimpimimpi yang terdapat pada Program AIKID, dimana mimpi utamanya adalah terciptanya label smart city untuk Kota Malang. Untuk mencapai smart city tidak akan mudah, perlu beberapa tahap untuk dapat mencapainya. Perlu intensitas yang tinggi untuk dapat mencapainya. Intensitas yang dimaksud adalah diselenggarakan Program AIKID setiap tahun. dengan begitu, mimpi atau khayalan merubah label Kota Malang menjadi smart city dapat diwujudkan meskipun untuk mencapainya butuh waktu yang relatif lama.

\section{d) Rangsangan (Excitement)}

Pada Program AIKID ini terdapat rangsanganrangsangan yang dapat menunjukan adanya suatu inovasi dan kreativitas. Ransangan yang dimaksud adalah motto "Kota Pendidikan" yang tertera pada Tri Bina Cita Kota Malang, masyarakat yang semakin pintar, dan juga perkembangan teknologi saat ini. Berdasarkan pengamatan yang dilakukan oleh peneliti, tiga hal tersebut dapat dikatakan sebagai rangsangan yang memacu adanya program ini. Program AIKID ini dibuat untuk mengikuti arus tiga hal tersebut, karena jika tidak dilakukan dapat membuat standar pelayanan publik Pemerintah Kota Malang tidak terlalu memuasan. Program ini juga merangsang seluruh SKPD Kota Malang untuk mengingkatkan inovasi dan kreativitas mereka. Hal ini terlihat dari rangkaian program ini, dimana pada awalnya memperlombakan seluruh SKPD untuk melakukan inovasi dan kreativitas dalam situs mereka masing-masing, dan nantinya situs-situs terbaik akan mendapatkan penghargaan yang setimpal.

e) Pemeriksaan Secara Nyata (Reality Check)

Sebelum program ini dilaksanakan, peneliti melihat bahwa Diskominfo melakukan analisis terkait program ini, maksudnya adalah apakah program ini akan berhasil mewujudkan mimpi-mimpi yang dicanangkan sebelumnya atau tidak.

Berdasarkan temuan di atas, Program AIKID ini membuat kreativitas lebih baik, dimana saat ini terdapat berbagai produk kreatif yang dihasilkan. Sebenarnya produk yang dimaksud yaitu berbagai fitur online yang sudah ada, namun setelah adanya program ini penulis melihat adanya perubahan yang lebih baik. Perubahan yang dihasilkan ini dapat dikatakan perubahan yang berguna sebagai peningkatan kesempurnaan dari fitur yang sudah ada. Berdasarkan perubahan tersebut berdampak pada kenyamanan masyarakat saat ini, dimana masyarakat sudah lebih mempercayai pemerintah saat ini.

\subsection{Intensitas Yang Akan Dicapai}

Intensitas suatu program pemerintah nantinya akan menentukan hasil yang dikeluarkan juga. Intensitas yang akan dicapai dalam hal ini adalah seberapa sering program ini dijalankan, dan pencapaian apa yang nantinya akan dikeluarkan. Dari pengamatan oleh peneliti, sangat telihat bahwa program ini nantinya akan mendapatkan hasil yang maksimal. Jika dilihat dari berjalannya program ini selama dua tahun, telah banyak perubahan dan perkembangan yang terjadi pada seluruh SKPD. Perkembangan yang dimaksud adalah aktifnya seluruh situs SKPD di Kota Malang. Keaktifan situs ini juga tidak terlepas dari rangkaian program ini, yaitu pemberian pelatihan kepada perwakilan sumberdaya dari setiap SKPD. Hasil yang didapat dari pelatihan ini adalah tersedianya sumberdaya aparatur yang memahami tentang mengurus suatu situs.

Peneliti juga melihat adanya pergeseran yang terdapat pada Pemerintahan Kota Malang. Saat ini Kota Malang dapat dikatakan telah mencapai elemen dari smart city, yaitu smart governance (pemerintahan cerdas), karena smart governance dapat dicapai setiap kota dengan cara penggunaan ICT di dalam pemerintahannya. Hal ini dibuktikan dengan penggunaan situs oleh setiap SKPD dan kualitas dari isi situs seluruh SKPD, dimana sudah terdapat banyak inovasi didalamnya. Mulai dari keterbukaan informasi, dan juga terdapatnya berbagai pelayanan. Berdasarkan hal itulah Kota Malang dapat dikatakan sudah mencapai elemen smart governance.

Berdasarkan pemaparan diatas dapat disimpulkan bahwa dua tahun perjalanan Program AIKID ini dinilai sudah cukup memuaskan. Jika intensitas program ini terus ditingkatkan atau dilaksanakan setiap tahun, pada tahun selanjutnya akan mencapai elemen-elemen dari smart city dan pada akhirnya dapat mewujudkan smart city untuk Kota Malang. 


\section{Kesimpulan}

Berdasarkan hasil penelitian, maka dapat disimpulkan beberapa hal, antara lain sebagai berikut:

a) Bahwa pengembangan e-government melalui penerapan Program Anugerah Inovasi dan Komunikasi Informasi Digital (AIKID) di Kota Malang dalam rangka mewujudkan smart city diukur dengan menggunakan indikator efektivitas dapat dikatakan cukup efektif. Hal ini dibuktikan dengan terpenuhinya seluruh dari isi indikator tersebut. Saat ini, setelah program ini berjalan di tahun kedua mengalami peningkatan di setiap situs layanan SKPD; dan

b) Seluruh situs layanan SKPD di Kota Malang telah aktif dan memiliki kualitas yang memadai. Selain itu, pelayanan-pelayanan yang terdapat pada setiap situs juga sudah dapat memudahkan masyarakat, sehingga tidak perlu berbelit-belit dan memakan waktu yang lama dalam memberikan pelayanan kepada masyarakat. Jika efektivitas Program AIKID ini dilakukan dalam intesitas tinggi, atau dalam intensitas waktu yang lama, smart city yang menjadi sasaran utama akan terwujud. Hal ini dibuktikan dengan sudah tercapainya salah satu elemen dari smart city, yaitu smart governance pada Kota Malang.

\section{Daftar Pustaka}

Akadun. (2009). Teknologi Informasi Administrasi. Bandung: Alfabeta.

Moleong, Lexy J. (1999). Metodologi Penelitian Kualitiatif. Bandung: Remaja Rosdakarya.

Miles, Mathew B., Michael Huberman, \& Johnny Saldana. (2014). Qualitative Data Analysis: A Methods Sourcebook. London: Sage Publication Ltd.

Rewansyah, Asmawi. (2010). Refomasi Birokrasi Dalam Rangka Good Governance. Jakarta: Yusaintanas Prima.

Sanjaya, Imam. (2012). Pengukuran Kualitas Layanan Website Kementerian KOMINFO dengan Menggunakan Metode Webqual 4.0. Jurnal Penelitian IPTEK-KOM, Volume 14, No. 1, Juni 2012, pp. 1-14.

Sinambela, L.P. (2010). Reformasi Pelayanan Publik; Teori, Kebijakan dan Implementasi, Cetakan Kelima. Jakarta: PT. Bumi Aksara.

Sukarelawati, Endang. (2013). MCW Desak Pemkot Malang Perbaiki Layanan Publik. [internet] tersedia melalui: http://www.antarajatim.com/ lihat/berita/104913/mcw-desak-pemkot-malangperbaiki-layanan-publik [diakses pada 10 Pebruari 2016].

Sutabri, Tata. (2005). Sistem Informasi Manajemen. Yogyakarta, Andi.
Sutopo, dan Adi Suryanto. (2003). Pelayanan Prima. Jakarta: Lembaga Administrasi Negara Republik Indonesia.

Suwarno, Yogi. (2008). Inovasi di Sektor Publik. Jakarta, STIA-LAN Press.

Undang-undang Nomor 25 Tahun 2009 tentang Pelayanan Publik. 